\title{
CONTEXTUAL TEACHING AND LEARNING (CTL) UNTUK MENINGKATKAN KEMAMPUAN BERPIKIR KREATIF SISWA
}

\author{
Winarti \\ Program Studi Pendidikan Fisika, Fakultas Sains dan Teknologi \\ UIN Sunan Kalijaga Yogyakarta \\ wina_tarazka@yahoo.co.id
}

\begin{abstract}
Abstrak
Menanamkan kemampuan berpikir kreatif adalah bagian yang sangat penting dalam proses pembelajaran. Penelitian ini bertujuan untuk mengetahui: (1) efektifitas pembelajaran dengan Contextual Teaching and Learning (CTL) terhadap keterampilan berpikir kreatif siswa, (2) perbedaan keterampilan berpikir kreatif pada siswa yang mengikuti pembelajaran denan Contextual Teaching and Learning (CTL).Jenis penelitian ini adalah quasi experiment dengan pretest-posttest control group design. Variabel yang digunakan meliputi variabel bebas berupa pembelajaran Contextual Teaching and Learning (CTL) variabel terikat berupa keterampilan berpikir kreatif. Populasi dalam penelitian ini adalah kelas X SMA Negeri 2 Banguntapan. Penentuan sampel dilakukan dengan teknik random sampling sehingga kelas yang terpilih sebagai kelas eksperimen adalah kelas X-2 dan X-3 sebagai kelas kontrol. Instrumen yang digunakan berupa soal pretest-posttest yang bermuatan indikator kemampuan berpikir kreatif. Data rating scale dianalisis bnbnm statistik deskriptif dan data soal pretest-posttest dianalisis menggunakan statistik inferensial (analisis uji-t dengan taraf signifikansi 5\%). Hasil penelitian menunjukkan bahwa (1) pembelajaran dengan Contextual Teaching and Learning (CTL) lebih efektif dibandingkan dengan kelas kontrol, (2) dari 5 indikator kemampuan berpikir kreatif yaitu berpikir lancar, fleksibilitas, orisinalitas, elaborasi dan evaluasi ternyata mempunyai nilai yang lebih tinggi dibandingkan kemampuan berpikir kreatif siswa kelas kontrol.
\end{abstract}

Kata Kunci: Contextual Teaching and Learning (CTL), keterampilan berpikir kreatif.

\section{PENDAHULUAN}

Kreativitas merupakan aspek penting dalam membangun manusia. Kecenderungan abad saat ini sumber daya alam bukan lagi menjadi hal yang utama dalam menyokong suatu bangsa. Sumber daya manusia menjadi ujung tombak maju atau tidaknya suatu bangsa. Akan sangat dibutuhkan manusia produktif dan inovatif dalam segala bidang kehidupan. Kreatifitas diperlukan dalam perkembangan awal dari pikiran seseorang. Lembaga pendidikan adalah tempat yang paling penting untuk menanamkan dan memelihara bakat kreatif siswa. Menurut Munandar (2002), Kreativitas dapat dipandang sebagai produk dari hasil pemikiran atau prilaku manusia dan sebagai proses pemikiran berbagai gagasan dalam menghadapi suatu persoalan atau masalah. Kreativitas juga dapat dipandang sebagai proses bermain dengan gagasan gagasan atau unsur-unsur dalam pikiran, sehingga merupakan suatu kegiatan yang penuh tantangan bagi siswa yang kreatif. Menurut Costa (2001) Kreativitas dan berfikir kreatif keduanya secara konsep terkait tetapi tidak identik. Kreativitas merupakan payung gagasan yang di dalamnya ada berpikir kreatif. Menurut De Potter (dalam Supriadi, 1994) terdapat 4 langkah penting dalam berpikir kreatif yaitu : (1) tidak selalu mudah puas dan tidak selalu mau menerima apa adanya. (2) tidak terpaku pada satu cara (3) selalu ingin 
mempertajam rasa ingin tahu (4) selalu melakukan pelatihan otak.

Kreativitas juga dapat didefinisikan sebagai kemampuan untuk menghasilkan solusi untuk masalah yang rumit dan kompleks (Saskia,et al, 2012). Proses berpikir kreatif merupakan berpikir konvergen untuk menangkap situasi, membuat evaluasi dan mempertimbangkan konsekuensi dari solusi yang dipilih (Adzliana Mohd Daud, 2012) Kreatifitas terintegrasi dalam pengetahuan dan proses sains (Sema Aydin, 2014). Menurut Munandar (2002) kreativitas seseorang tidak muncul begitu saja, tapi perlu ada pemicu. Kratifitas adalah hasil dari proses interaksi antara individu dengan lingkungannya, yang berarti bahwa lingkungan dapat menunjang atau menghambat kreativitas seseorang. Selanjutnya Munandar menjelaskan ciri-ciri ketrampilan berfikir kreatif adalah sebagai berikut :

(1) ketrampilan berfikir lancar (fluency)

(2) ketrampilan berfikir luwes (flexibility)

(3) ketrampilan berfikir orsinil (originality)

(4) ketrampilan berfikir rinci (elaboration)

Elemen kreativitas dalam pendidikan ditekankan pemerintah melalui UndangUndang Republik Indonesia Nomor 20 Tahun 2003 tentang Sistem Pendidikan Nasional (Sisdiknas, 2003:9) yakni: "Pendidikan Nasional berfungsi mengembangkan kemampuan membentuk watak serta peradaban bangsa yang bermartabat dalam rangka mencerdaskan kehidupan berbangsa, bertujuan untuk mengembangkan potensi perkembangan peserta didik agar menjadi manusia yang beriman dan bertakwa kepada Tuhan Yang Maha Esa, berakhlak mulia, sehat, berilmu, cakap, kreatif, mandiri, dan menjadi warga Negara yang demokratis serta bertanggung jawab".

Dengan demikian, secara tersirat hal tersebut mengindikasikan bahwa dalam pendidikan perlu ditekankan kreativitas dalam rangka pengembangan potensi peserta didik. Pengembangan tersebut perlu dilatihkan kepada peserta didik melalui berbagai kegiatan pembelajaran yang memacu kemampuan berpikir kreatif. Kerja kreatif membutuhkan penerapan dan penyeimbangan tiga kemampuan berpikir, diantaranya adalah kemampuan analitis, kemampuan kreatif dan praktis (Sternberg dan Grigorenko, 2010:87). Kemampuan kreatif secara umum dipahami sebagai kreativitas. Adapun kreativitas penuh membutuhkan suatu keseimbangan antara kemampuan analitis, kritis dan praktis. Sedangkan dalam Munandar (1985:88) dijelaskan bahwa terdapat lima karakteristik kemampuan berpikir kreatif (aptitude) yakni meliputi keterampilan berpikir lancar, keterampilan berpikir luwes (fleksibell), keterampilan berpikir orisinal, keterampilan memperinci (mengelaborasi), dan keterampilan menilai (mengevaluasi). Sedangkan karakteristik afektif (nonaptitude) yakni meliputi rasa ingin tahu, bersifat imajinatif, merasa tertantang oleh kemajemukan, sifat berani mengambil resiko, dan sifat menghargai.

Belajar kreatif tidaklah secara kebetulan akan tetapi membutuhkan proses yang mendukung tercapainya kemampuan tersebut. Untuk merangsang belajar kreatif, diperlukan persiapan antara lain dengan menyiapkan suatu lingkungan kelas yang merangsang anak-anak untuk belajar kreatif. Menurut Feldhusen dan Triffinger menyatakan bahwa lingkungan kreatif dapat tercipta dengan memberikan pemanasan (menuntut perilaku kreatif siswa sesuai dengan rencana pelajaran), pengaturan fisik (memperhatikan pengaturan fisik di dalam kelas), kesibukan di dalam kelas (diskusi) dan guru sebagai fasilitator (terbuka dalam menerima gagasan dari siswa) (Munandar, 1985:79).

Menurut Trianto (2012:107) konteks memberikan arti, relevansi dan manfaat penuh terhadap belajar. Pembelajaran kontekstual merupakan suatu pendekatan pembelajaran yang mengakui dan menunjukkan kondisi alamiah dari pengetahuan. Melalui hubungan di dalam dan di luar kelas suatu pendekatan pembelajaran konstekstual menjadikan pengalaman lebih relevan dan berarti bagi siswa dalam membangun pengetahuan yang akan mereka terapkan dalam pembelajaran seumur hidup. Konsep yang disajikan mengkaitkan materi pembelajaran yang dipelajari siswa dengan konteks di mana materi tersebut digunakan dan berhubungan 
dengan gaya ataupun cara belajar siswa. Adapun komponen utama pembelajaran kontekstual menurut Ditjen Dikdasmen (2002:10) yakni meliputi:

konstruktivisme (constructivism),

menemukan (inquiry), (3) bertanya (questioning), (4) masyarakat belajar (learning community), (5) pemodelan (modelling), (6) refleksi (reflection) dan (7) penilaian yang sebenarnya (authentic assesment).

Pembelajaran kontekstual merupakan sebuah konsep belajar yang mampu mengaitkan antara materi yang diajarkan dengan situasi nyata siswa dan mendorong untuk menghubungkan pengetahuan yang dimiliki dengan penerapannya dalam kehidupan sehari-hari. Adanya penerapan ketujuh komponen tersebut, maka dalam pelaksanaan pembelajaran kontekstual akan menghantarkan pada kegiatan student center serta pemberdayaan terhadap siswa.

Fisika merupakan bagian dari sains. Ganijanti Aby Sarojo (2002:2) menyatakan bahwa fisika adalah ilmu pengetahuan yang mempelajari benda-benda di alam, gejalagejala, kejadian-kejadian alam serta interaksi dari benda di alam tersebut. Dengan demikian maka terdapat interaksi yang erat antara fisika dengan lingkungan hidup. Mempelajari fisika tidak dapat melepaskan diri dari aspek observasi atau eksperimen dan berpikir taat asas. Observasi atau eksperimen merupakan kegiatan yang berkaitan dengan pengamatan gejala fisika.

CTL bukan berarti memaksakan suatu konsep pembelajaran terintegrasi dengan lingkungan, melainkan diupayakan melalui penyesuaian dengan berbagai konsep serta konteks yang sedang dipelajari. Mengingat fisika merupakan salah satu pembelajaran terkait dengan alam sekitar, maka diharapkan adanya korelasi antara fisika dengan wawasan lingkungan. Oleh karena itu konsep materi terkontekstualisasikan dalam kehidupan sehari-hari, dengan demikian kemampuan berpikir siswa kian kreatif dalam memecahkan permasalahan yang terkait dengan kondisi yang berada di lingkungan sekitar. Landasan filosofi Contextual Teaching and Learning (CTL) adalah konstruktivisme, yaitu filosofi belajar yang menekankan bahwa belajar tidak hanya sekedar menghafal, akan tetapi perlu mengkonstruksikan pengetahuan dibenak diri. Hal tersebut dimaksudkan bahwa pengetahuan tidak dapat dipisahkan menjadi fakta-fakta atau proporsi yang terpisah, akan tetapi mencerminkan keterampilan yang dapat diterapkan. Dengan demikian, maka pada pembelajaran kontekstual lebih menekankan pada skenario pembelajaran yakni berupa kegiatan tahap demi tahap yang dilakukan guru dan siswa dalam mencapai tujuan pembelajaran yang diharapkan dengan acuan penerapan ketujuh komponen $C T L$ secara holistik.

Berdasarkan uraian kajian permasalahan tersebut, maka penulis berupaya mendesain alternatif solusi berupa pengintegrasian pembelajaran fisika pada materi suhu dan kalor dengan model Contextual Teaching and Learning (CTL) terhadap kemampuan berpikir kreatif peserta didik tingkat SMA/MA. Keterpaduan pembelajaran fisika melalui model tersebut diharapkan berdampak terhadap kemampuan berpikir kreatif peserta didik

\section{METODE PENELITIAN}

Penelitian ini merupakan penelitian quasi experimental design tipe pretestposttest control group design. Deskripsi skematis penelitian disajikan sebagai berikut:

Tabel 1. Desain Penelitian

\begin{tabular}{lllll}
\hline Group & Pretest & Treatment & Posttest \\
\hline Eksperimen & $\mathrm{O}_{1}$ & $\mathrm{X}$ & $\mathrm{O}_{2}$ & \\
\hline Kontrol & $\mathrm{O}_{3}$ & $\mathrm{Y}$ & $\mathrm{O}_{4}$ & \\
\hline \multicolumn{2}{c}{ Populasi } & yang & digunakan & pada
\end{tabular}
penelitian ini adalah kelas X SMA Negeri 2 Banguntapan terdiri atas 209 peserta didik yang terbagi dalam tujuh kelas. Sementara teknik sampling yakni menggunakan simple random sampling, di mana pengambilan sampel dilakukan secara acak tanpa memperhatikan strata yang ada dalam populasi. Pengujian dilakukan dengan menggunakan bantuan software SPSS 17.0. hasil pengujian disajikan sebagai berikut:

Tabel 2. Uji Normalitas Populasi

\begin{tabular}{lll}
\hline \multirow{2}{*}{ Kelas } & $\begin{array}{l}\text { Kolmogorov- } \\
\text { Smirnov }^{a}\end{array}$ & $\begin{array}{l}\text { Shapiro- } \\
\text { Wilk }\end{array}$ \\
\cline { 2 - 3 } & Sig. & Sig. \\
\hline $\mathrm{X}-1$ & 0,095 & 0,102 \\
\hline
\end{tabular}


JPFK, Vol. 1 No. 1, Maret 2015 : 1-8

\begin{tabular}{|c|c|c|}
\hline X-2 & 0,069 & 0,511 \\
\hline X-3 & 0,096 & 0,092 \\
\hline X-4 & 0,200 & 0,375 \\
\hline X-5 & 0,000 & 0,006 \\
\hline X-6 & 0,200 & 0,640 \\
\hline X-7 & 0,200 & 0,605 \\
\hline
\end{tabular}

enam kelas berdistribusi normal sedangkan kelas X-5 berdistribusi tidak normal. Hal ini disebabkan karena nilai signifikansi kelas menunjukkan lebih dari $0,05(\alpha \geq 0,05)$. Enam kelas lainnya berdistribusi normal. Sementara pengujian homogenitas menunjukkan bahwa ketujuh kelas homogen atau mempunyai varian yang sama karena nilai signifikasni pada levene's test sebesar 0,118 . Besarnya nilai lebih besar dari 0,05 ( $\alpha$ $\geq 0,05)$, artinya ketujuh kelas memiliki variansi sama. Selanjutnya dilakukan pengundian kelas, kelas yang dijadikan sebagai kelas eksperimen yakni kelas X-2, sementara X-3 sebagai kelas kontrol

Variabel pada penelitian ini meliputi variabel bebas (independent variable) yakni pembelajaran fisika model Contextual Teaching and Learning (CTL) sementara variabel terikat (dependent variable) adalah kemampuan berpikir kreatif peserta didik pada ranah kognitif).

Pada penelitian ini digunakan teknik analisis deskriptif dan inferensial. Untuk mengetahui tingkat kemampuan berpikir kreatif yakni menggunakan analissi uji-t dengan taraf signifikansi sebesar 5\%. Untuk mengetahui tingkat kemampuan berpikir kreatif yakni dengan menggunakan selisih nilai posttest dan pretest. Perbedaan peningkatan kemampuan berpikir kreatif siswa yang mengikuti pembelajaran model Contextual Teaching and Learning (CTL) lingkungan dengan siswa pada kelas kontrol (metode demonstrasi) dapat dilihat dari nilai rata-rata $N$-Gain.

\section{HASIL DAN PEMBAHASAN}

1. Implementasi Pemebelajaran Fisika Model Contextual Teaching and Learning (CTL) terhadap Keterampilan Berpikir Kreatif

Treatment diberikan pada kelas eksperimen dengan menggunakan model pembelajaran

Contextual Teaching and Learning (CTL) sedangkan pada kelas kontrol pembelajaran dilakukan dengan menggunakan metode demonstrasi. Setelah diberikan treatment pada kedua kelas tersebut kemudian dilakukan posttest. Berikut disajikan data hasil pretest dan posttest kelas eksperimen dan kontrol

Tabel 8. Deskripsi Nilai Pretest Kelas Eksperimen dan Kontrol

\begin{tabular}{lll}
$\begin{array}{l}\text { Ukuran } \\
\text { Penyebaran Data }\end{array}$ & $\begin{array}{l}\text { Kelas } \\
\text { Eksperimen }\end{array}$ & $\begin{array}{l}\text { Kelas } \\
\text { Kontrol }\end{array}$ \\
\hline Mean & 35,26 & 37,50 \\
\hline Minimum & 14,00 & 16,00 \\
\hline Maximum & 67,00 & 74,00 \\
\hline Range & 53,00 & 58,00 \\
\hline Variance & 151,03 & 160,19 \\
\hline Std. Deviation & 12,29 & 12,66 \\
\hline
\end{tabular}

Berdasarkan tabel 8. diketahui bahwa ratarata dan varian kelas eksperimen dan kontrol bernilai setara. Tabel tersebut menunjukkan bahwa kedua kelas bersifat homogen. Setelah dilakukannnya pengujian normalitas dan homogenitas kemudian dilanjutkan dengan uji t. Deskripsi hasil posttest yang disajikan sebagai berikut:

Tabel 9. Deskripsi Nilai Posttest Kelas Eksperiman dan Kontrol

\begin{tabular}{|c|c|c|}
\hline $\begin{array}{l}\text { Ukuran } \\
\text { Penyebaran } \\
\text { Data }\end{array}$ & $\begin{array}{l}\text { Kelas } \\
\text { Eksperimen }\end{array}$ & $\begin{array}{l}\text { Kelas } \\
\text { Kontrol }\end{array}$ \\
\hline Mean & 76,36 & 70,71 \\
\hline Maximum & 92,5 & 87,5 \\
\hline Minimum & 60,00 & 55,00 \\
\hline Range & 32,50 & 32,50 \\
\hline Variance & 71,02 & 62,89 \\
\hline Std.Deviation & 8,43 & 7,93 \\
\hline
\end{tabular}

bahwa nilai rata-rata kelas eksperimen lebih tinggi dari kelas kontrol. Besarnya varian dan simpangan baku kelas eksperimen berbeda dan lebih tinggi jika dibandingkan dengan kelas kontrol.

Pembelajaran yang diberikan pada siswa yaitu dengan memberi permasalahan yang berkaitan dengan kehidupan sehari-hari dan sangat dekat hubungannya dengan materi yang tengah dipelajari. Permasalahan yang diberikan merupakan permasalahan kontekstual yang memicu siswa untuk berargumen atau berpendapat sesuai dengan pola pikirnya. Hal ini dimaknai bahwa masalah yang disajikan harus mendorong 
JPFK, Volume 1, Nomor 1, Maret 2015 : 1 - 8

siswa untuk mencari dan menggunakan beberapa sudut pandang untuk menyelesaikannya, mengeksplorasi berbagai strategi yang dilakukan, serta memperbaiki cara yang telah dilakukan. Pembelajaran kontekstual yang dilakukan pada penelitian ini mengaitkan antara materi suhu, kalor dan perubahannya dengan situasi dunia nyata dan mendorong siswa membuat hubungan antara pengetahuan yang dimilikinya dengan penerapannya dalam kehidupan sehari-hari.

Selama proses kegiatan pembelajaran model Contextual Teaching and Learning (CTL) pelaksanaaan disesuaikan dengan langkah-langkah pada pembelajaran kontekstual. Melalui strategi tersebut, penanaman kemampuan berpikir kreatif yang mengacu pada lima indikator yang meliputi berpikir lancar, fleksibel, berpikir orisinal, elaborasi dan keterampilan menilai (evaluasi). Kelima indikator tersebut menekankan peran guru terhadap siswa untuk berperilaku kreatif diantaranya melalui latihan yang tidak hanya memiliki satu jawaban (memiliki berbagai alternatif jawaban), mentolerir jawaban yang menyimpang, menekankan pada proses bukan hasil, membuat siswa menjadi berani untuk mencoba, serta memberikan keseimbangan antara yang terstruktur dan spontan dalam merespons pembelajaran. bahwa pembelajaran model Contextual Teaching and Learning (CTL) dapat meningkatkan kemampuan berpikir kreatif siswa lebih baik daripada pembelajaran pada kelas kontrol. Pembelajaran kontekstual diterapkan pada kelas eksperimen, dimana siswa diarahkan untuk menggali pengetahuan yang dimilikinya untuk menemukan konsep baru dari permasalahan yang diberikan siswa didorong untuk menggali informasi dari suatu permasalahan, yang selanjutnya guru membimbing siswa untuk melakukan penyelidikan dan berdiskusi untuk menemukan prosedur penyelesaian dengan memanfaatkan informasi dan pengetahuan yang dimilikinya. Dengan diskusi siswa dapat saling tukar menukar ide, pendapat, pemikiran, informasi/pengalaman dengan siswa yang lainnya. Dalam pembelajaran dengan diskusi ini memberi peluang kepada siswa untuk terlibat secara aktif dalam pembelajaran.

Hasil penelitian menunjukkan adanya perbedaan antara kelas eksperimen dan kontrol mengenai kemampuan berpikir kreatif melalui tes yang dilakukan terhadap kedua kelas tersebut. Adapun perbedaan tersebut ditunjukkan dengan nilai rata-rata siswa melalui pretest dan posttest kedua kelas yang disajikan sebagai berikut:

Hasil penelitian ini menunjukkan

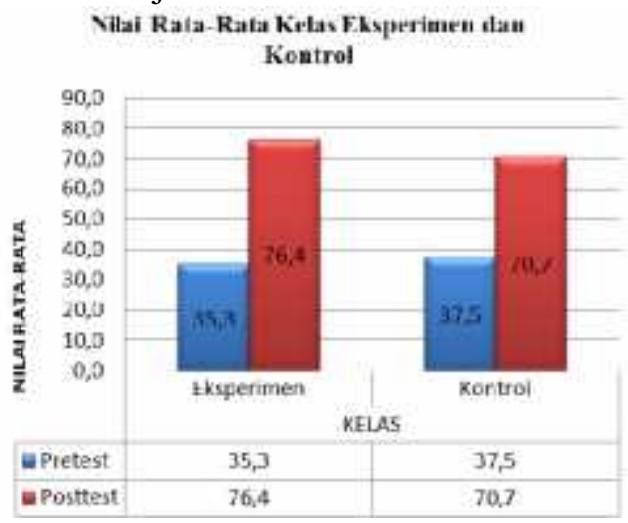

Gambar 1. Skor Rata-Rata Pretest dan Posttest Kelas Eksperimen dan Kontrol

Pada gambar 1. menunjukkan bahwa antara kedua kelas pada saat dilakukan pretest memiliki kemampuan awal yang cenderung setara. Hal ini ditunjukkan dengan besarnya nilai rata rata kelas eksperimen sebesar 35,3 sedangkan kelas kontrol 37,5. Melalui treatment yang berbeda antara kelas eksperimen dan kontrol mengakibatkan perbedaan pula pada hasil akhir pada posttest. Kelas eksperimen diperoleh nilai posttest lebih tinggi dibandingkan kelas kontrol, dimana pada 
kelas eksperimen diperoleh nilai rata-rata sebesar 76,4 sedangkan kelas kontrol sebesar 70,7

\section{Efektifitas Model Contextual Teaching and Learning (CTL) terhadap Keterampilan Berpikir Kreatif}

Penyusunan pembelajaran khususnya pada penyusunan butir soal pretest-posttest di samping mengacu pada indikator pencapaian kompetensi juga akan mengacu pada indikator kemampuan berpikir kreatif. Kegiatan pembelajaran diupayakan mampu merangsang kemampuan berpikir kreatif siswa. Oleh karenanya diperlukan proses pembelajaran yang menjalin hubungan dialog akademik.

Berdasarkan penelitian yang telah dilakukan, diperoleh nilai besarnya rata-rata skor posttest kelas eksperimen 76,4 dan kelas kontrol sebesar 70,7 hal tersebut mendeskripsikan bahwa skor rata-rata posttest kelas eksperimen lebih tinggi dibandingkan dengan kelas kontrol. Oleh karenannya maka $\mathrm{H}_{\square}$ ditolak sedangkan $\mathrm{H}_{a}$ diterima yang artinya bahwa rata-rata skor posttest eksperimen lebih besar dibandingkan dengan kelas kontrol.

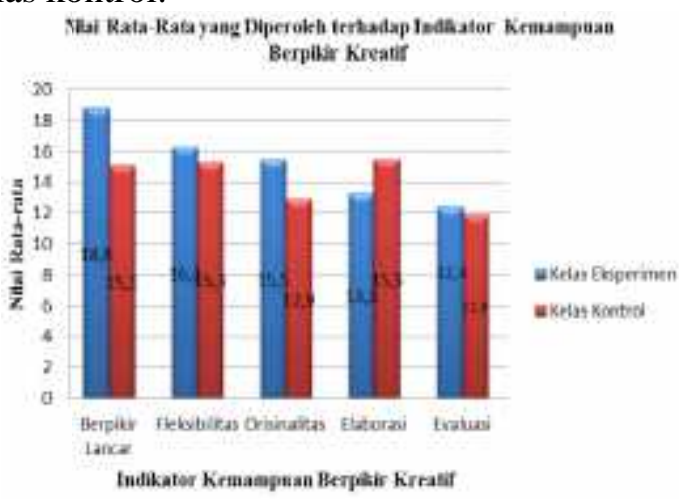

Gambar2. Nilai Rata-Rata yang Diperoleh pada Kelas Eksperimen dan Kontrol terhadap Indikator Kemampuan Berpikir Kreatif

Pada gambar 2. menunjukkan bahwa rata-rata skor yang diperoleh tiap indikator memiliki keberbedaan. Pada kelas eksperimen skor rata-rata tertinggi yakni pada keterampilan berpikir lancar dengan skor 18,8 , sedangkan skor rata-rata terendah yakni pada ketermpilan mengevaluasi dengan skor 12,4. Sedangkan pada kelas kontrol skor rata-rata tertinggi yakni pada ketermpilan mengelaborasi dengan skor 15,5
Tingkat efektivitas dari kedua sampel kelas tersebut dapat diketahui dengan menggunakan nilai gain yang telah dinormalkan (n-gain). Prosentase n-gain kelas eksperimen sebesar 63\% sedangkan kelas kolas kontrol sebesar 53\%. Berdasarkan pengkategorian tersebut, maka kelas eksperimen dikatakan lebih efektif dibandingkan kelas kontrol.

Pembelajaran dengan model Contextual Teaching and Learning (CTL) lebih efektif dibandingkan pembelajaran dengan pembelajaran dengan metode demonstrasi terhadap kemampuan berpikir kreatif siswa. Hal ini disebabkan karena selama berlangsungmya proses pembelajaran kelas eksperimen merangsang siswa untuk kreatif berpikir serta merespons atas pertanyaan yang disampaikan guru. Oleh karenannya siswa terdorong untuk menyelesaiakan berbagai permasalahan dengan alternatif penyelesaian. Kemampuan berpikir kreatif disajikan pula skor rataan yang berbeda pada tiap indikator kemampuan berpikir kreatif antara kelas eksperimen dan kontrol. Adapun skor rata-rata kemampuan berpikir kreatif tiap indikator sebagai berikut: 
dengan kelas kontrol.

Kegiatan yang memberikan masalahmasalah berupa pertanyaan-pertanyaan yang disesuaikan dengan lingkungan sekitar ternyata mampu membuat siswa berpikir kreatif karena mereka memberi banyak alasan jawaban di luar dugaan. Konsep suhu dan kalor sangat dekat hubungan nya dengan kejadian sehari-hari sehingga siswa mempunyai pengetahuan awal yang mereka bawa dalam pembelajaran di kelas. Hal ini berbeda dengan pembelajaran biasa yang tidak menggunakan pertanyaan-pertanyaan untuk mengungkap konsep dari siswa. Ketika diberi pertanyaan siswa akan berusaha menjawab dengan mengingat kembali gejala-gejala yang mereka pernah temui dan berusaha untuk menganalis dugaan mereka sampai mereka memberi jawaban di luar jawaban biasa. Ada kaitan antara memberi pertanyaan tersebut terhadap kemampuan berpikir kreatif siswa. Hal ini senada dengan yang diungkapkan oleh Hwang et al (2007) mendefinisikan kemampuan berpikir kreatif sebagai keterampilan kognitif untuk memberikan solusi terhadap suatu masalah atau membuat sesuatu yang bermanfaat atau sesuatu yang baru dari hal yang biasa (Hwang et al, 2004).

Berdasarkan penelitiannya yang berjudul Multiple Representation Skills andCreativity Effects on Mathematical Problem Solving Using a Multimedia Whiteboard, mereka menyimpulkan bahwa kemampuan elaborasi, yang merupakan salah satu komponen berpikir kreatif, merupakan faktor kunci yang menstimulasi siswa untuk mengkreasi pengetahuan mereka dalam aktivitas pemecahan masalah. Kemampuan berpikir kreatif mendukung kinerja individu dalam aktivitas pemecahan masalah.

Penelitian lain oleh dikemukakan Treffinger dalam Alexander (2007) yang menyatakan bahwa kemampuan berpikir kreatif diperlukan untuk memecahankan masalah, khususnya masalah kompleks. Tanpa kemampuan berpikir kreatif, individu sulit mengembangkan kemampuan imajinatifnya sehingga kurang mampu melihat berbagai alternatif solusi masalah. Hal ini menggambarkan bahwa keterampilan berpikir kreatif memungkinkan seorang individu memandang suatu masalah dari berbagai perspektif sehingga memungkinkannya untuk menemukan solusi kreatif dari masalah yang akan diselesaikan.

\section{KESIMPULAN}

Kesimpulan penelitian ini adalah.

1. Pembelajaran dengan Contextual Teaching and Learning (CTL) efektif digunakan untuk meningkatkan kemampuan berpikir kreatif siswa dibandingkan dengan kelas kontrol

2. Pembelajaran dengan Contextual Teaching and Learning (CTL) mampu meningkatkan kemampuan berpikir kreatif dibuktikan dari 5 indikator kemampuan berpikir kreatif yaitu berpikir lancar, fleksibilitas, orisinalitas, dan evaluasi ternyata mempunyai nilai yang lebih tinggi dibandingkan kemampuan berpikir kreatif siswa kelas kontrol. Pada indikator elaborasi ternyata tidak meningkat dengan nilai yang lebih rendah dibandingkan dengan kelas kontrol.

\section{Daftar Rujukan}

Adzliana Mohd Daud, Jizah Omar, Punia Turiman \& Kamisah Osman. Creativity in Science Education. Social and Behavioral Sciences Journal Vol 59. 2012. Page 467 474.

Alexander, K. L. 2007. Effects Instruction in Creative Problem Solving on Cognition, Creativity, and Satisfaction among Ninth Grade Students in an Introduction to World Agricultural Science and Technology Course. Disertasi pada Texas Tech University. [Online]. Tersedia:http://etd.

lib.ttu.edu/theses/ available/etd01292007

144648/unrestricted/Alexander_Kim _Dissertation.pdf. 
Costa, A.L. 2001. Developing Mind A Resource book for Teaching Thinking. Virginia USA :ASCD.

Eko Putro Widoyoko. 2012. Teknik Penyusunan Instrumen Penelitian. Yogyakarta: Pustaka Pelajar.

Hwang, Wu-Yuin, Chen, Nian-Shing, Dung, Jian-Jie, dan Yang, Yi-Lun. (2007). Multiple Representation Skills and Creativity Effects on Mathematical Problem Solving using a Multimedia Whiteboard System. International Forum of Educational Technology \& Society Journals. ISSN 14364522.[Online].:http://www.ifets.info labstrack.php.

Munandar, S.C.U. 2002. Pengembangan Kreativitas Anak Berbakat. Jakarta : PT Rineka Cipta.

Saskia Jaarsveld, Thomas Lachmann, Cees van Leeuwen. Creative reasoning across developmental levels: Convergence and divergence in problem creation. Intelligence Journal Vol 40 . 2012. Page 172188

Sema Aydın Ceran, Seda Çavuş Güngören, Nilda Boyacioğlu. Determination of scientific creativity levels of middle school students and perceptions through their teachers. European Journal of Research on Education, 2014, Special Issue: Contemporary Studies in Education, page 47-53

Supriadi, D. 1994. Kreativitas Kebudayaan dan Perkembangan IPTEK. Bandung :Alfabeta. 